\title{
DINAMIKA SPATIO-TEMPORAL DAMPAK ERUPSI GUNUNG KELUD DI KABUPATEN KEDIRI
}

\author{
Purwanto $^{1}$, Marhadi Slamet $\mathbf{K}^{2}$ \\ Email:purwanto.fis@um.ac.id, marhadi.slamet.fis@um.ac.id
}

\begin{abstract}
Abstrak: Tujuan penelitian ini mengkaji sejauh mana dampak erupsi gunung Kelud Tahun 2014 terhadap dinamika perubahan lahan. Metode yang digunakan dalam penelitian ini yaitu survey dengan menggunakan data penginderaan jauh multi temporal dan multi resolusi. Data penginderan jauh yang digunakan yaitu citra Landsat ETM+, Landsat 8, Aster, Quickbird, SRTM, dan Hyperion. Hasil penelitian menunjukkan pasca erupsi gunung Kelud 2014 telah menyebabkan dinamika spatio temporal arah erupsi dan perubahan lahan. Hasil kajian dari tahun 1901 sampai 2014 secara makro arah erupsi G. Kelud selalu ke arah Barat dan beberpaa erupsi susulan ke Arah Timur. Pada skala meso arah erupsi mengarah ke Selatan, Barat, dan Utara. Hal ini dipengaruhi oleh arah angin yang mengarah ke Barat Daya. Pada skala mikro kerusakan lahan dapat dilihat dari perubahan kawah G. Kelud di mana kawah 1990 berupa danau, 2007 anak gunung Kelud, dan 2014 kawah kering.
\end{abstract}

Kata Kunci : Dinamika, Spasio-temporal, Dampak erosi.

\section{PENDAHULUAN}

Gunung Kelud merupakan gunungapi strato yang termasuk gunungapi teraktif di Indonesia. Gunung ini secara administratif terletak di tiga wilayah yaitu Kabupaten Kediri, Blitar, dan Malang dengan ketinggian $1731 \mathrm{~m}$ dpal. Secara geografis terletak pada $7^{\circ} 56^{\prime} \mathrm{LS}$ dan $112^{\circ} 18,5^{\prime}$ BT. Pada Tanggal 14 Pebruari 2014 terjadi erupsi yang cukup hebat yang memberikan dampak luar biasa terhadap dinamika spasial dampak perubahan lahan.

Dinamika spasial dampak erupsi gunung Kelud terjadi sejak awal terjadi erupsi gunung Kelud. Kusumadinata (1979), Zainuddin (2013), menyebutkan catatan sejarah erupsi Gunung Kelud dari tahun 1000-2007 telah terjadi sebanyak 33 kali. Ini berarti hingga tahun 2014

${ }^{1}$ Universitas Negeri Malang
${ }^{2}$ Universitas Negeri Malang telah terjadi erupsi sebanyak 34 kali. Dari kejadian erupsi tersebut dinamika spasial terhadap jumlah korban jiwa baru dapat dideteksi dengan baik sejak tahun 1901 hingga sekarang.

Sejak erupsi tahun 1990, gunung Kelud hingga saat ini telah terjadi 2 kali erupsi yaitu erupsi tahun 2007 dan 2014. Erupsi tahun 2007 secara spatial tidak memberikan dampak yang berarti, karena erupsi hanya bersifat lokal. Hasil proses erupsi tersebut menghasilkan pengangkatan sumbat lava pada area kawah. Dampak dari proses ini menyebabkan perubahan pada kawah yang awalnya berbentuk danau kawah menjadi anak gunung Kelud baru.

Tahun 2014 aktivitas erupsi kembali terjadi pada 13 Pebruari 2014 dengan 
letusan yang hebat dan bersifat exsplosive. Surono, (2014) menyatakan bahwa material yang dikeluarkan Gunung Kelud pada erupsi 2014 mencapai 100200 juta meter kubik. Dampak dari erupsi ini menyebabkan perubahan pada bentuk kawah yaitu munculnya lubang kawah baru dalam kawah lama. Anak gunung Kelud yang terbentuk tahun 2007 telah hancur dan berubah menjadi kawah baru.

Erupsi yang bersifat exsplosif telah menyebabkan lontaran material vulkanik setinggi 17 kilometer. Dampak dari memuntahan lava pijar yang disertai semburan abu vulkanik dan kerikil telah menyebabkan hujan abu vulkanik di beberapa wilayah yaitu Blitar Kediri, Solo, Yogyakarta, Purwokerto, Cilacap dan beberapa daerah di Bandung Jawa Barat (www.Kompas.com diakses 14-022014).

Lorentzos (1988) dan Langran (1989), telah melakukan penelitian tentang spatio-temporal. Penelitian telah difokuskan pada database pengindekan untuk menjawab pertanyaan dasar mengenai data secara efisien. Menurut Gudmundsson (2008), model analisis spatio-temporal dapat dibedakan menjadi beberapa model yaitu: 1) Spatio-temporal berbasis query, e.g. 'Report all entities that visited region $S$ during the time interval [t1, t2]. 2) Spatial nearest neighbours given a time interval, e.g. 'Report the entity closest to point $p$ at time t. 3) Temporal nearest neighbours given a spatial region, e.g. 'Report the first entity visiting region $S$.'

Untuk menganalisis dinamika dampak erupsi gunung Kelud diperlukan data yang bersifat spatio temporal. Data Spatio-Temporal merupakan data spasial yang nilainya berubah dalam jangka waktu tertentu. Ini berarti bawah ruang dan waktu merupakan entitas yang penting di dalam analisis spatio temporal. Gudmundsoon (2008) menegaskan bahwa entitas spasial objek dapat berupa data titik, garis, maupun area yang bergerak dari waktu ke waktu. Perubahan entitas objek ini akan membentuk suatu pola pergerakan dalam satu set entitas.

Ilustrasi data spatio-temporal dapat diilustrasikan gambar 1. Berdasarkan gambar tersebut dapat dijelskan bahwa objek A pada waktu $T_{1}$ mengalami perubahan menjadi $A B$ pada waktu $T_{2}$, dan berubahan menjadi B pada waktu $T_{n}$. Data spatio-temporal terus akan mengalami perubahan sampai akhir dari proses perubahan. 
62

Purwanto, Marhadi Slamet K. Dinamika Spatio-Temporal Dampak Erupsi Gunung Kelud Di Kabupaten Kediri

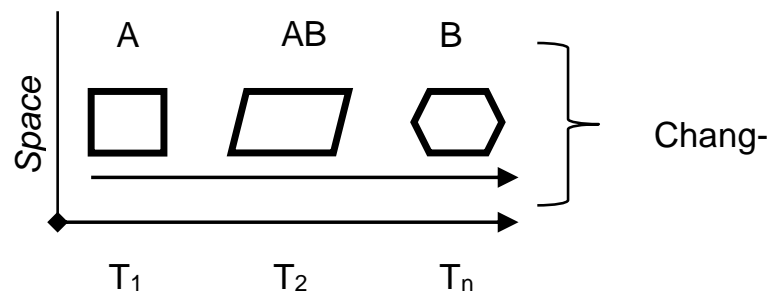

Gambar 1. Deskripsi data Spatio-Temporal (Shafry, 2006; Yulianti, 2009)

Analisis spatio-temporal yang dikembangkan bersifat komputerais, sehingga yang dihasilkan adalah sebuat model. Dalam kajian ini analisis spasial didasarkan fenomena yang telah terjadi pada dunia nyata. Pada kajian ini dinamika spasio temporal yang dimaksud adalah mendiskripsikan data, fakta, maupun fenomena Gunung Kelud pada masa lampau hingga saat ini berdasarkan data geospatial.

Selanjutnya Shafry, 2006; K.Venkateswara Rao, 2011; Mobasheri, et.al., 2014, bahwa semua fenomena dipermukaan bumi tidak dapat lepas dari waktu. Inilah elemen yang paling penting saat menentukan terjadinya fenomena. Untuk menggambarkan fenomena tersebut ada tiga perntayaan penting yaitu apa, dimana, dan ketika. Pertayaan "Apa" digunakan untuk mengenali fenomena, "Dimana" pertayaan yang berkaitan dengan lokasi geografis dan "When" mengungkapkan faktor waktu. Ilustrasi dari ketiga pertanyaan tersebut dapat digambarkan sebagaimana berikut.

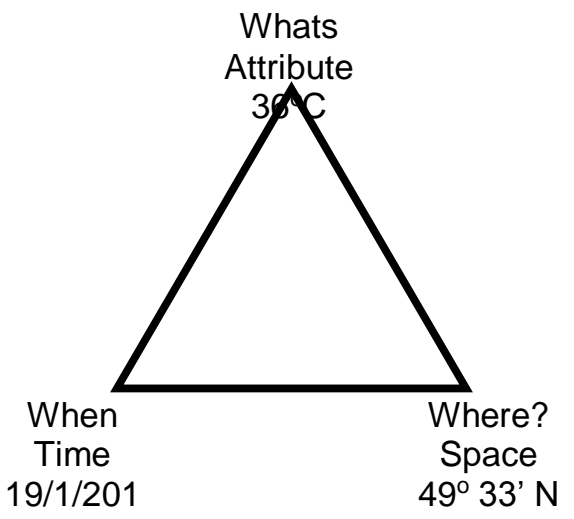

Gambar 2. Model Triadic ruang, waktu dan atribute (Shafry, 2006)

K.Venkateswara Rao, 2011, menegaskan kuatnya hubungan ruang, waktu, dan atribute dalam analisis spatio-temoral dapat dikembangkan beberapa model analisis yaitu:

Semantik spasial: kategori ini berisi beberapa kriteria yang berhubungan 
dengan aspek spasial murni seperti struktur ruang, orientasi/arah, pengukuran dan topologi.

Semantik Temporal: kategori ini berkaitan dengan sifat waktu dan unsur dasar yang digunakan untuk menggambarkan granularity, kerapatan waktu, urutan waktu, transaksi, dan permasalahan yang dapat dimodelkan dengan elemen waktu secara terus menerus.

Semantik spatio-temporal: kategori ini berisi kriteria yang paling penting dan menantang yang merupakan gabungan dari data spasial dan model temporal. Tipe ini dapat berupa keadaan yang sederhana, jenis perubahan, evolusi dalam ruang dan waktu, topologi ruang-waktu, identitas objek, dan dimensi.

Selanjutnya perkembangannya analisis spatio-temporal diterapkan dalam berbagai bentuk kajian dalam pemodelan misalnya analisis perubahan iklim [1], sistem transportasi, monitoring hutan [2], penyebaran penyakit [3], sistem informasi geografis temporal[4] dan sistem lingkungan [5] kebencanaan (6) proses spasial, temporal dan atribut elemen data untuk penemuan pengetahuan.

Gunung Kelud merupakan gunung yang aktif dengan karakteristik erupsi exsplosif. Dalam setiap erupsi memberikan dampak terhadap perubahan lahan yang sulit untuk diprediksi. Gunung ini memiliki material erupsi piroklastik yang mengalir, lontaran, ledakan lateral, longsoran puing-puing dan lava mengalir memiliki dampak langsung terhadap lingkungan (Marti, et, al., 2005).

Untuk meminimalisasi dampak erupsi gunung Kelud ini maka perlu dipelajari sifat dan karakter erupsi dan dampaknya berdasarkan ruang dan waktu, serta dampak proses dan hasil proses yang diakibatkannya. Untuk itu perlu dilakukan kajian dinamika spatiotemporal dampak erupsi Gunung Kelud.

\section{METODE}

Penelitian merupakan penelitian survey yang menggunakan data penginderaan jauh multi resolusi, multi temporal, yang diintegrasikan dengan Sistem Informasi Geografi. Data citra satelit yang digunakan yaitu citra Landsat ETM+, Landsat 8, citra Quickbird, dan model DEM ASTER. Selain data juga didukung data skunder dari hasil penelitian terkait dengan gunung Kelud untuk melihat peristiwa jauh sebelumnya. Analisis dilakukan dengan membagi zona ruang yaitu skala makro, meso dan mikro. Zona ruang skala makro mengkaji dampak erupsi pada wilayah yang luas. Zona ruang skala Meso mengkaji endapan material vulkanik, dan zona ruang skala mikro mengkaji dampak perubahan morfologi kawah Gunung Kelud. Analisis spatio-temporal dilakukan dengan melakukan komparasi dengan menggunakan data dan teknologi geospasial yaitu penginderaan jauh dan Sistem Informasi Geografi. Berikut adalah diagram alir proses metode penelitian. 
64

Purwanto, Marhadi Slamet K. Dinamika Spatio-Temporal Dampak Erupsi Gunung Kelud Di Kabupaten Kediri

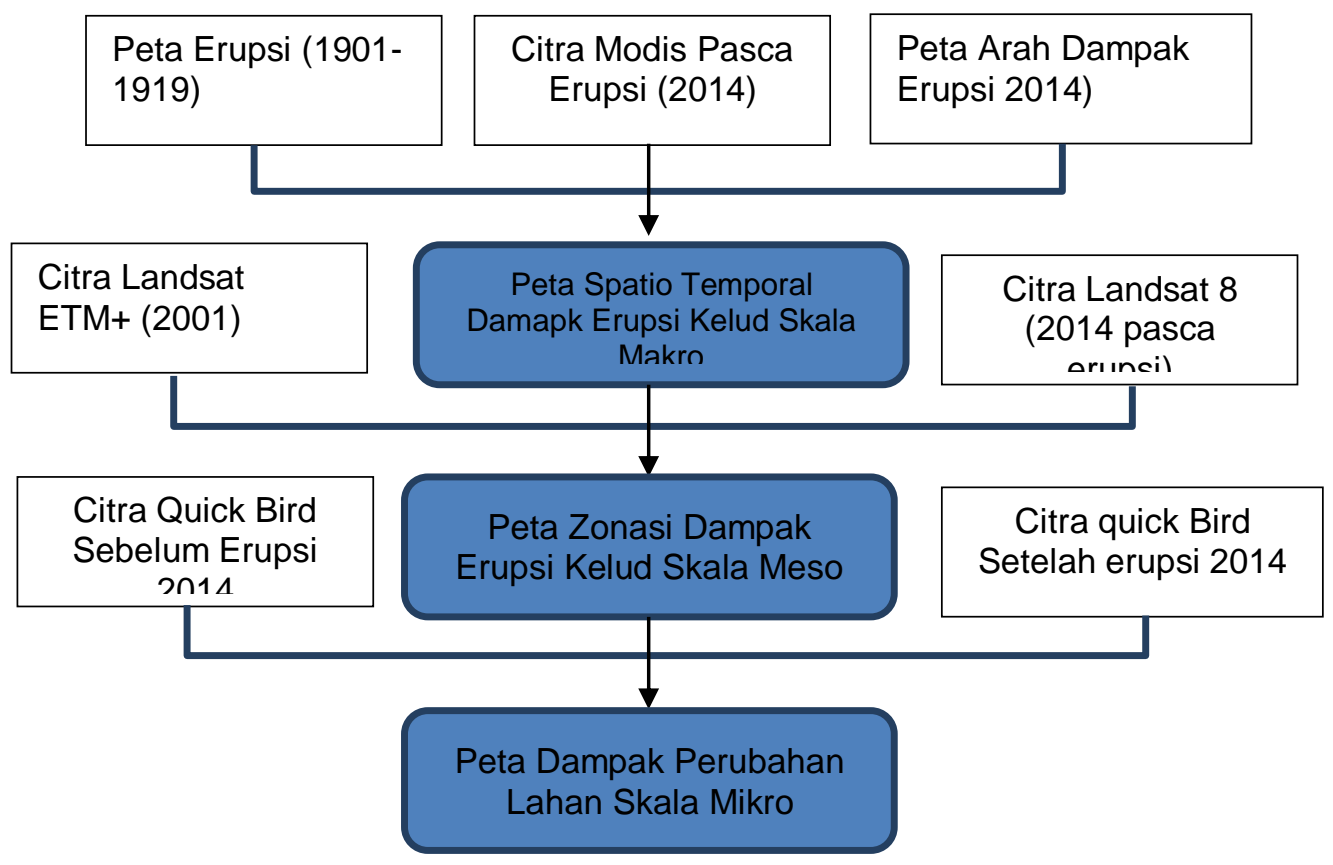

Gambar 3. Diagram alir penelitian

\section{PEMBAHASAN}

Manfred J, et al., (2000) menggambarkan dinamika arah deposit hujan abu dari letusan 1901 dan 1919 Gunungapi Kelud diadaptasi dari KEMMERLING (1921). Pada periode 1901 sebaran material abu vulkanik tersebar ke wilayah Barat. Jangkauan abu vulkanik pada waktu tersebut mencapai Jakarta. Selama periode 1919 sebaran abu vulkanik Gunung Kelud tersebar di dua arah. Awan dengan ketinggian rendah membawa abu yang tersebar ke arah timur sampai Bali dan awan tinggi membawa material tersebar ke Barat dengan jangkauan wilayah Yogyakarta, Bandung, Jakarta dan Banten.

Jika dibandingkan dengan hasil erupsi 2014 dengan erupsi sebelumnya, erupsi tahun 2014 memiliki dampak spatial yang lebih luas. Ditinjau dari trend arah erupsi secara umum memiliki kecenderungan ke arah Barat. Hal ini perlu diperhatikan dalam melakukan mitigasi bencana dampak dari erupsi Gunung Kelud. Pola spatio-temporal dari dampa erupsi tersebut dapat dilihat pada gambar 3 berikut ini. 


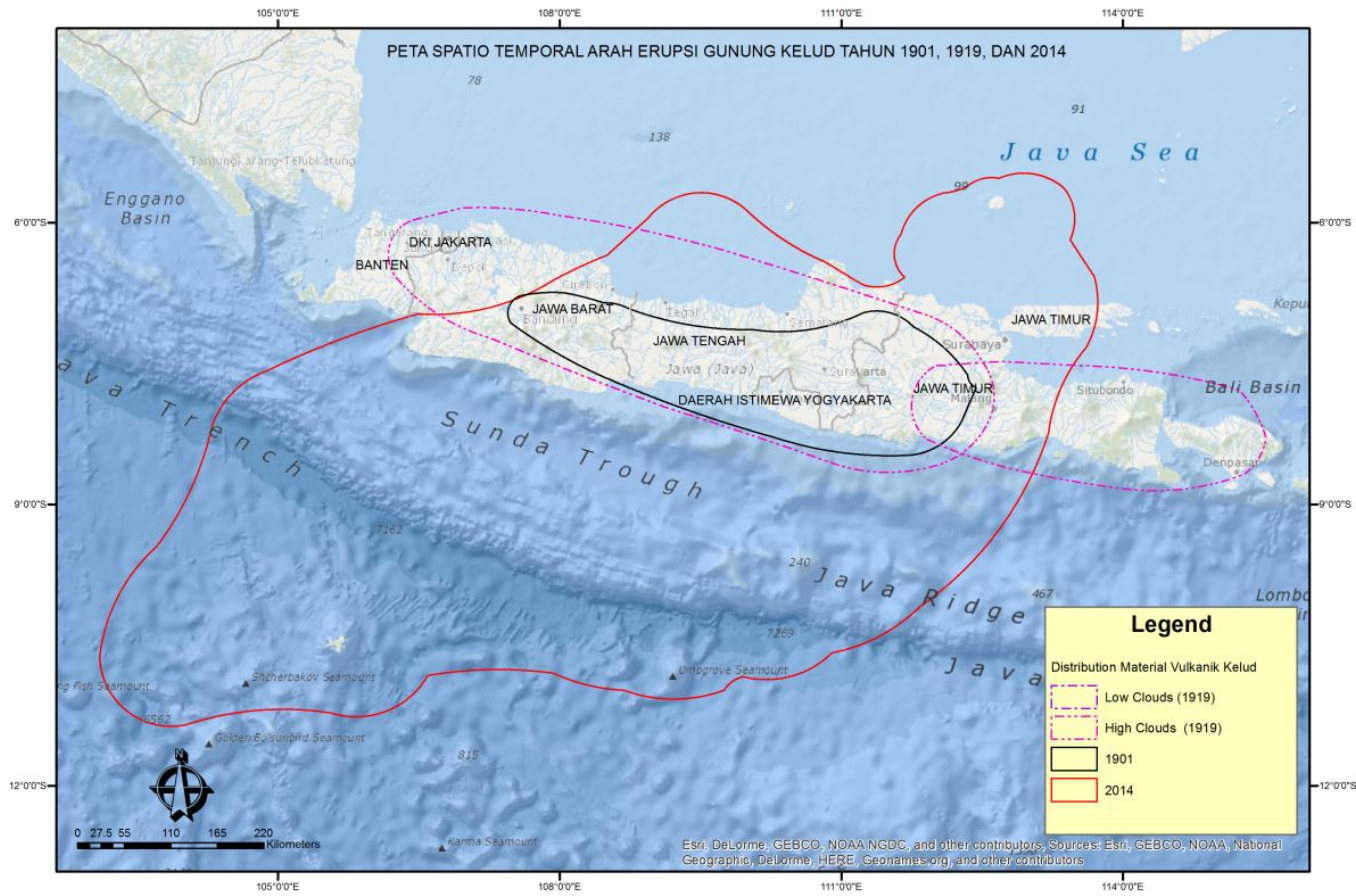

Gambar 4. Trend Spatio-Temporal sebaran sulphur eprusi Gunung Kelud pada tahun 1901, 1919 dan 2014 (Sumber: Manfred, et., al., esa.int.)

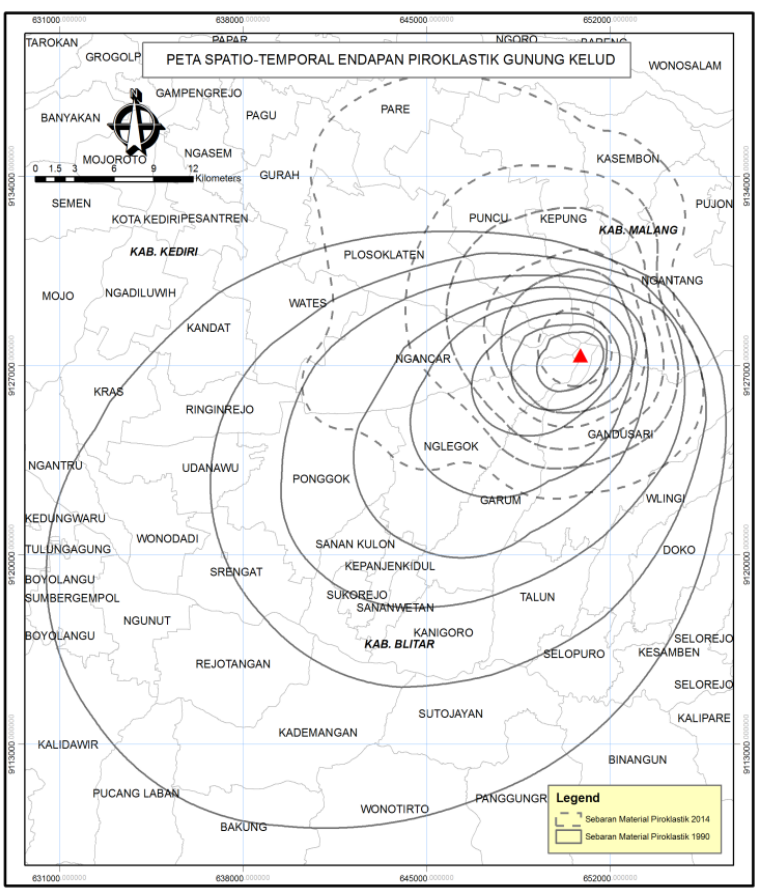

Gambar 5. Trend Spatio-Temporal Skala Meso sebaran materil piroklastik pada tahun 1990 dan 2014 
66

Purwanto, Marhadi Slamet K. Dinamika Spatio-Temporal Dampak Erupsi Gunung Kelud Di Kabupaten Kediri

Berdasarkan kajian skala meso, ternyata terdapat trend yang berbeda antara sebaran material piroklatik tahun 1990 dengan tahun 2014. Endapan material piroklastik yang didominasi oleh pumice rata-rata terendapan pada jarak $\pm 44 \mathrm{Km}$ tahun 1990 dan \pm 30 meter pada tahun 2014. Zainuddin, et al., (2013), erupsi gunung kelud menghasilkan endapan batuan vulkanik berupa endapan aliran piroklastika, jatuhan piroklastika, freatik, dan lahar yang menutupi seluruh wilayah di sekitar gunung api tersebut sampai mencapai jarak lebih dari $40 \mathrm{~km}$. Ini berarti pada zona radius $\pm 40 \mathrm{Km}$ merupakan zona yang rentan terhadap endapan material piroklastik. Namun radius ini terjadi pada sisi selatan dan barat yang di mana arah erupsi selalu mengarah ke daerah tersebut. Hal ini dapat dibuktikan dengan endapan gunung Kelud Muda dan endapan lahar terdapat di daerah Selatan, Barat, dan Utara.

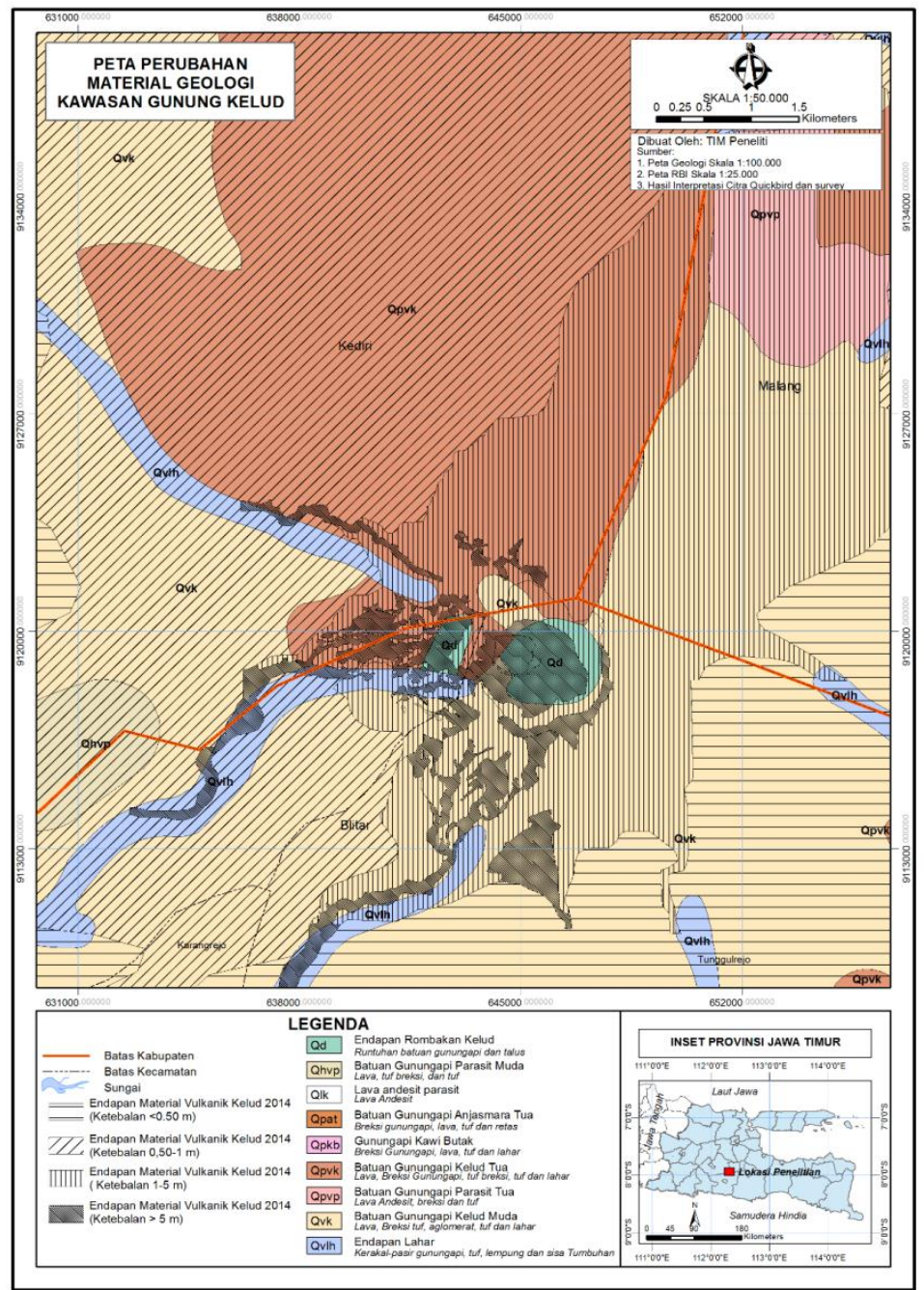

Gambar 6. Sebaran material endapan piroklastik dan peta geologi 
Dari gambarn peta geologi sudah sangat jelas bahwa daerah yang berada disisi Utara, Barat dan Selatan memiliki tingkat kerawanan dari bahaya jatuhan material piroklastik. Tebal endapan bervariasi $0.5 \mathrm{~m}$ sampai $>5 \mathrm{~m}$. Endapan yang tersebar di atas $5 \mathrm{~m}$ umumnya berada di daerah lembah sungai dan disekitar dinding kawah dalam dan luar.

Kelud merupakan stratovolcano komposit dibangun oleh akumulasi banyak aliran lava (sisi timur dan timur laut) aliran piroklastik, lonjakan piroklastik dan deposit lahar dari aktivitas termuda gunung berapi. Deposit puinglongsoran, beberapa ratus meter tebal mendasari deposit, dan diproduksi oleh kemiringan kegagalan sisi barat gunung berapi (Thouret et al., 1998), Manfred J, et al., (2000).

Letusan terbaru (1990) yang diproduksi menengah- $\mathrm{K}$ basaltik andesit dan batu apung scoria dengan plagioklas, orthopyroxene, clinopyroxene dan magnetit sebagai fenokris (Bourdier et al., 1997). Komposisi ini sebanding dengan magma diproduksi oleh aktivitas letusan selama abad terakhir. Tubuh Gunung Kelud sebagian besar tersusun oleh endapan-endapan jatuhan dan aliran piroklastika.

Endapan-endapan tersebut merupakan material lepas yang sangat mudah tererosi dan tertransportasi oleh air hujan untuk membentuk endapan Lahar di daerah yang lebih rendah. Aliran lahar yang terjadi setelah letusan merupakan bahaya sekunder yang cukup serius karena dapat terjadi dalam kurun waktu yang cukup lama setelah letusan berakhir.
Pada skala mikro, bentuk perubahan dinamikan lahan yang lain yaitu perubahan morfologi kawah gunung Kelud. Wirakusumah, (1991), Humaida, et, al., (2011) menjelaskan dinamika perubahan kawah Gunung kelud hingga saat ini telah terjadi 10 kali perpindahan kawah. Namun pada dekade 1990, 2007, dan 2014 meskipun terjadi erupsi secara besar tidak terjadi pergseran kawah, akan tetapi yang mengalami perubahan adalah morfologi kawah. Dinamika perubahan tersebut dapat dilaporkan bahwa kawah yang terbentuk hasik erupsi 1990 adalah danau kawah, 2007 danau kawah tertutup oleh sumbat lava atau anak kelud, dan 2014 membentuk lubang kepundan baru dengan karakter kawah tidak berair.Dampak erupsi lain yaitu tertutupnya terowongan lahar, terkuburnya fasilitas wisata, dan perubahan jalur pendakian. Berdasarkan hasl tersebut maka dampak erupsi gunung Kelud terhadap dinamika Lahan perlu dikaji secara mendalam.

Berdasarkan peta geologi kawasan gunung Kelud tersusun atas beberapa formasi batuan dengan kompoisi yang berbeda. Formasi penyusunnya yaitu: 1) Batuan Gunung kelud muda (Qvk) dengan tersusun atas material lava, breksi tuf, aglomerat, tuf dan lahar. Sebarannya batuan kelud muda, mendominasi pada lereng selatan dan barat baik kabupaten Blitar maupun Kediri sampai lereng kaki bawah. 2) Endapan rombakan kelud (Qd) yang tersusun atas material runtuhan batuan gunungapi dan talus. Endapan ini tersebar pada kawasan kubah lava dan lereng atas sebelah barat yang masuk Kabupaten Kediri dan Blitar. 3) Endapan la- 
68

Purwanto, Marhadi Slamet K. Dinamika Spatio-Temporal Dampak Erupsi Gunung Kelud Di Kabupaten Kediri

har (Qvlh) yaitu kerakal pasir gunungapi, tuf, lempung, dan sisa tumbuhan. Endapan lahar tersebar pada lembah sungai yang berhulu di lereng atas kelud dan dataran rendah. dan 4) Batuan gunung kelud tua (Qpvk) yang tersusun atas material lava, breksi gunungapi, tuf breksi, dan lahar, yang tersebar disisi tenggara, lereng kaki.

Erupsi gunung Kelud tahun 2014 menambah panjang dan tebal struktur perlapisan material vulkanik muda daerah tersebut. Endapan vulkanik 2014 secara partikulat tersebar hingga radius 1000 $\mathrm{km}$, namun material endapat terpusat pada radius $5 \mathrm{~km}$. Berdasarkan hasil pemetaan dapat diketahui luas sebaran dari hasil endapan material piroklastik gunung Kelud yang berpengaruh terhadap dinamika lahan yaitu struktur geologi permukaan. Endapan material piroklastik tersebut memiliki sebaran dan ketebalan yang berbeda. Endapan secara lepas terdistribusi dengan ketebalan yang tidak merata. Adapun distribusi sebaran endapan material piroklastik dipaparkan pada Tabel 1.1 berikut ini.

Tabel 1. Hasil endapan material vulkanik Gunung Kelud yang berpengaruh terhadap struktur geologi.

\begin{tabular}{lll}
\hline No & GEOLOGI & Luas (Ha) \\
\hline 1 & Endapan Material Vulkanik Kelud 2014 <0.50 m & 75115.01 \\
2 & Endapan Material Vulkanik Kelud 2014 0,50-1 m & 7763.28 \\
3 & Endapan Material Vulkanik Kelud 2014 1-5 m & 2749.08 \\
4 & Endapan Material Vulkanik Kelud 2014 > 5 m & 438.93 \\
\hline
\end{tabular}

Sumber: Hasil interpretasi dan Survey 2014

Dari endapan material piroklastik yang secara signifikan berpengauh terhadap struktur geologi yaitu pada endapan yang berada $>5 \mathrm{~m}$ yang memiliki luas 438,93 Ha. Material endapan sebagaian besar didominasi piroklastis yaitu bom, lapilli, pumice, pasir dan debu. Endapan lahar umumnya tersebar di sekitar kawah, alur sungai dan lembah yang merupakan kantong-kantong endapan lahar erupsi sebelumnya. Endapan tertinggi terakumulasi di Sungai putih dengan ketinggian mencapai $40 \mathrm{~m}$. Selain itu hasil erupsi 2014 juga menutupi sebagian batuan gunungapi Kelud Muda yang berada disisi selatan. Demikian halnya dengan batuan gunungapi kelud tua sebagian juga tertutup oleh material endapan 2014 yang berada di sisi utara sebagaimana gambar 6 di atas.

Berdasarkan peta tersebut sebaran material piroklastik gunung kelud hasil erupsi 2014 mengarah ke Utara dan Barat. Namun Endapan material terbesar berada pada wilayah Selatan dan Barat. Pada wilayah tersebut rata-rata endapan material vulkanik memiliki ketebalan $>5 \mathrm{~m}$ tercebak pada cekungan maupun lembah. Akumulasi endapan dengan dinamika tinggi terjadi pada wilayah lereng yang berada di sungai. 


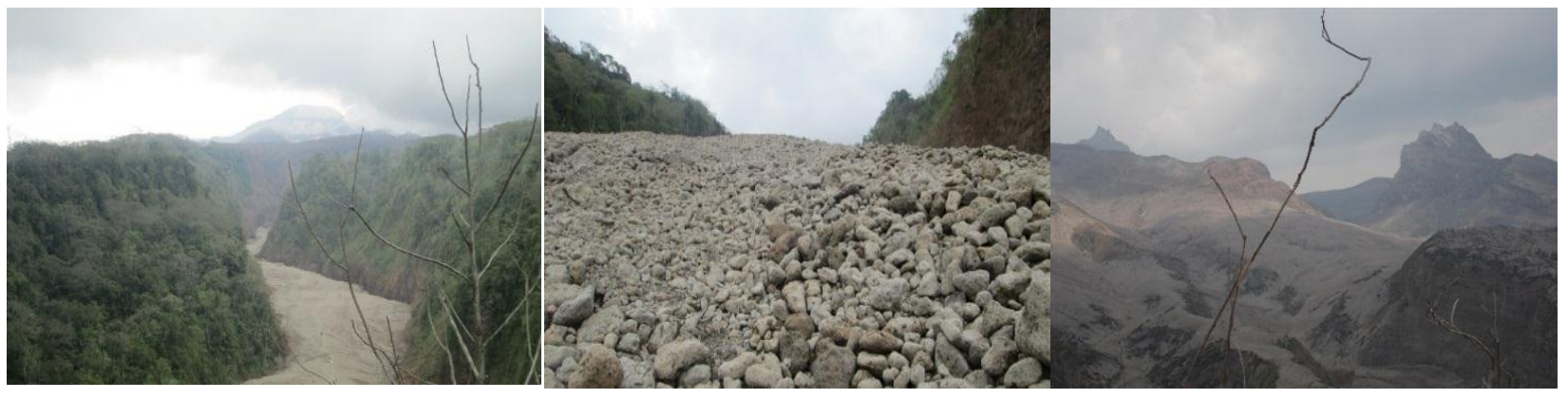

Gambar 7. Dinamika endapan piroklasik pada dinding kawah dan akumulasi endapan di sungai Tahun 2014

Dinamika perubahan lahan terjadi pada kawah gunung Kelud. Dari hasil interpretasi dan analisis multitemporal dapat disajikan karakteristik perubahan morfologi dari kawah Gunung Kelud. Jauh sebelum erupsi 2014 gunung kelud telah mengalami beberapa erupsi yang diikuti dengan perpindahan lokasi kawah.

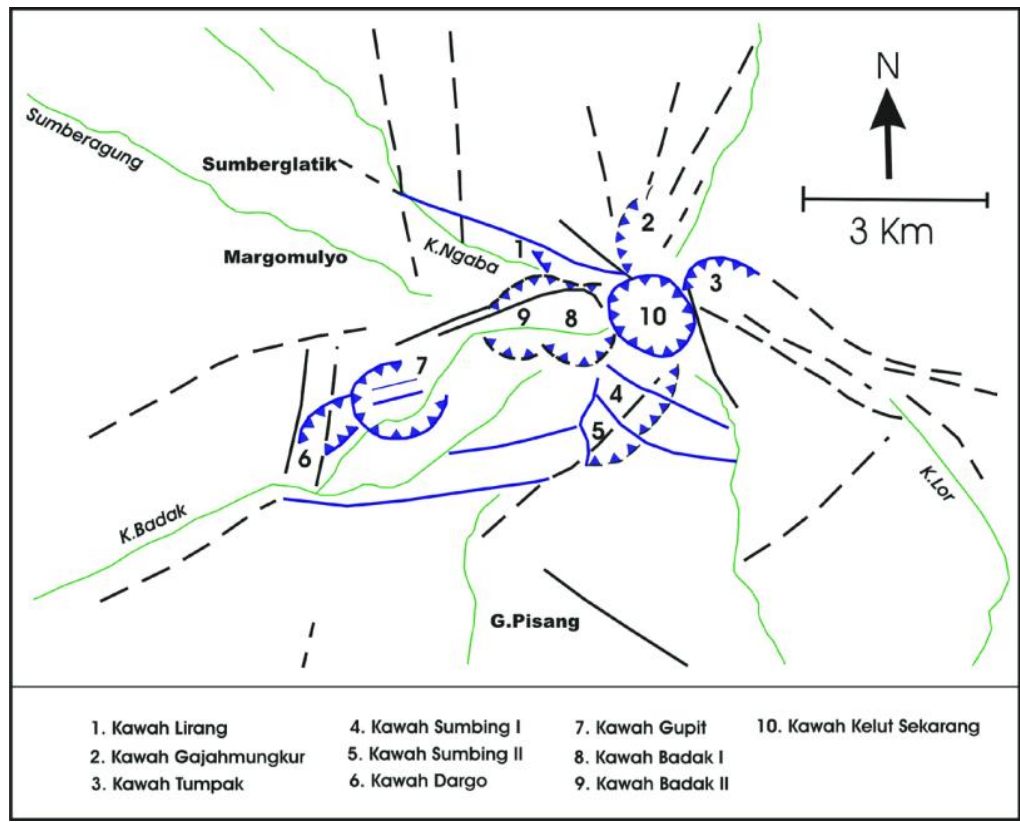

Gambar 8. Kronologi terbentuknya kawah Gunung Kelud (Wirakusumah, 1991)

Dari model kronologi tersebut gunung Kelud telah mengalami perpindahan kawah sebanyak 10 kali. Aktivitas erupsi 2014 juga memberikan warna perubahan dari morfologi kawah Gunung kelud sejak tahun 1990, 2007, dan 2014. Karaktersitik dinamika perubahan pada kawah gunung Kelud Sebagaimana gambar 1.5 Berikut ini: 
Purwanto, Marhadi Slamet K. Dinamika Spatio-Temporal Dampak Erupsi Gunung Kelud Di Kabupaten Kediri

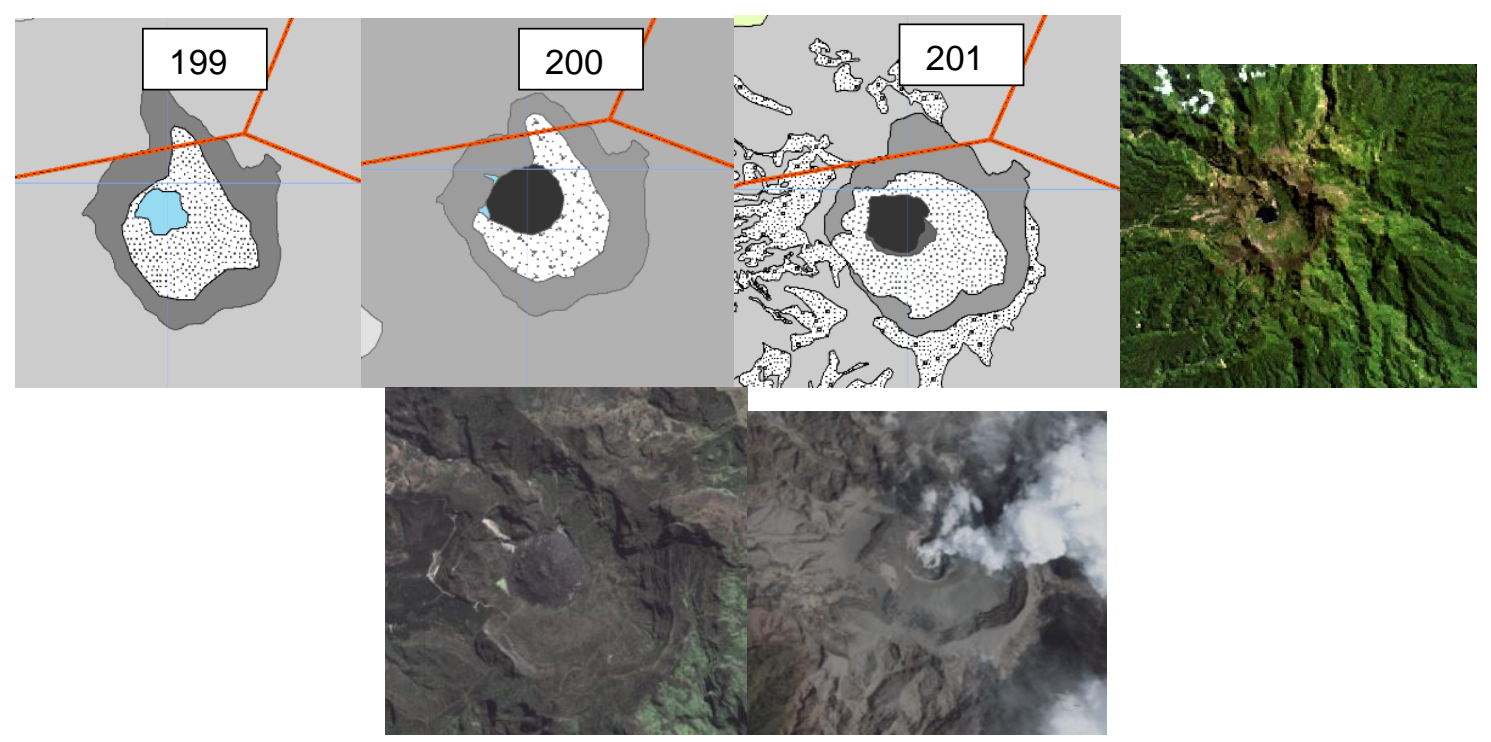

Gambar 8. Perubahan Morfologi Kawah Gunung Kelud daro tahun 1990-2014 (Hasil Analisis)

Luasan dari perubahan tersebut terdistribusikan sebagaimana dipaparkan pada Tabel 2 . berikut ini.

Tabel 2. Distribusi perubahan satuan lahan pada Kawah Gunung Kelud

\begin{tabular}{|c|c|c|c|c|c|c|c|}
\hline $\mathrm{NO}$ & Morfolog & 1990 & Luas $1990(\mathrm{Ha})$ & Morfologi 2007 & $\begin{array}{ll}\text { Luas } & 2007 \\
\text { (Ha) } & \end{array}$ & Morfologi 2014 & $\begin{array}{ll}\text { Luas } & 2014 \\
\text { (Ha) } & \end{array}$ \\
\hline \multirow{2}{*}{1.} & Lereng & Kawah & & $\begin{array}{ll}\text { Lereng } & \text { Kawah }\end{array}$ & & Lereng Kawah & \\
\hline & 1990 & & 91.43 & 1990 & 90.38 & 1990 & 69.69 \\
\hline 2. & $\begin{array}{l}\text { Danau } \\
1990\end{array}$ & Kawah & 9.04 & Danau Kawah & 0.74 & $\begin{array}{l}\text { Dinding Kawah } \\
\text { Luar Kawah } \\
\text { Baru }\end{array}$ & 2.46 \\
\hline 3. & $\begin{array}{l}\text { Sedimen } \\
1990\end{array}$ & Kawah & 65.07 & $\begin{array}{l}\text { Anak Kelud Hasil } \\
\text { Erupsi } 2007\end{array}$ & 20.82 & $\begin{array}{l}\text { Sedimen Ka- } \\
\text { wah kelud } 2014\end{array}$ & 70.80 \\
\hline \multirow[t]{2}{*}{4.} & & & & $\begin{array}{l}\text { Sedimen Kawah } \\
\text { Kelud } 1990\end{array}$ & 48.71 & $\begin{array}{l}\text { Kawah Baru } \\
2014\end{array}$ & 14.78 \\
\hline & Jumlah & & 165.54 & & 160.65 & & 157.73 \\
\hline
\end{tabular}

Dari tabel tersebut 2 perubahan yang tampak dari tahun 1990 ke tahun 2007 adalah perubahan danau kawah yang berubah menjadi anak kelud dan tahun 2014 anak kelud hilang menjadi kawah kering.

Untuk melihat gambaran secara menyeluruh perubahan yang tampak terlihat pada daerah kawah Gunung Kelud dikaji dari tahun 1990-2014. Sebagaimana hasil analisis perubahan dapat dilihat perkembangan morfologi Kawah tahun 1990 yang terdiri dari 3 bagian yaitu lereng kawah dengan luas 91,43 Ha, Sedimen kawah dengan luas 9,04 Ha, dan Danau Kawah dengan luas 65,07 Ha. Erupsi tahun 2007 lereng kawah mengalami perubahan luas yaitu 90,38 Ha, danau kawah 
mengalami perubahan menjadi $0,74 \mathrm{Ha}$, dan anak kelud seluas 20,82 Ha, dan sedimen kawah menjadi 48,71 ha. Erupsi tahun 2014 menyebabkan perubahan mor- fologi baru yaitu lereng kawah berubah menjadi 69,69 Ha, dinding/kawah baru 2,46 Ha, Kawah baru 14,78 Ha, dan sedimen kawah kelud 70,80 Ha.

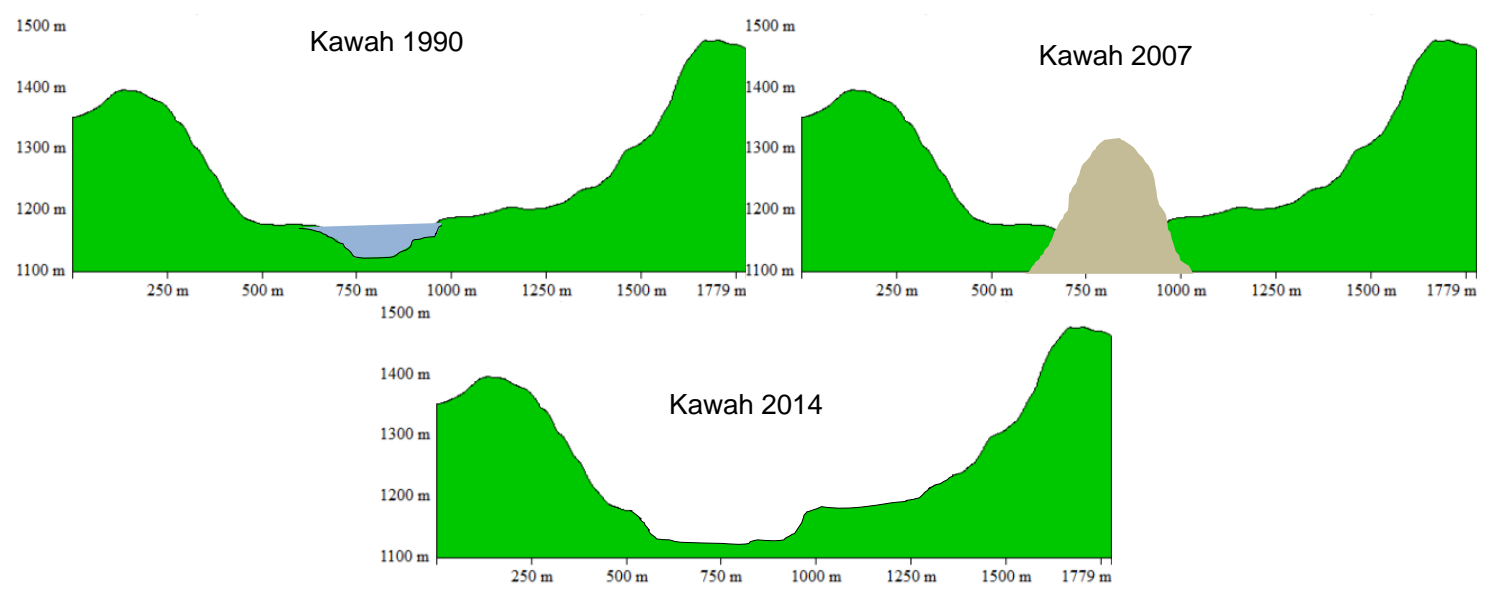

Gambar 9. Penampang Kawah Kelud Tahun 1990-2014

\section{KESIMPULAN}

Berdasarkan uraian hasil penelitian tersebut maka dapat disimpulkan bahwa:

Erupsi Gunung Kelud memiliki dinamika spatio-temporal. Dinamika spastio temporal dapat dilihat dari aspek arah letusan dari tahun 1901, 1919,1990 dan 2014. Dari dinamika tersebut bahwa arah erupsi gunung Kelud selalu mengarah ke Barat dengan sesekali mengarah Ketimur, hal ini dipengaruhi oleh kondisi angin dan kuatnya tenaga letusan.

Pada skala meso dapat dilihat dampak dari kerusakan sumberdaya lahan khususnya pada radius 0-10 Km berupa tutupan abu vulkanik.

Dinamika pada skala mikro dapat dilihat dari trend perubahan kawah perpindahan kawah dan bentuk kawah.

\section{DAFTAR RUJUKAN}

http://esa.int

Humaida, H. et all. 2011. Pemodelan Perubahan Densitas dan Viskositas Magma serta Pengaruhnya terhadap Sifat Erupsi Gunung Kelud. Jurnal Geologi Indonesia, Vol. 6 No. 4 Desember 2011: 227-237

Joachim Gudmundsson, et all. 2008. Movement Patterns in SpatioTemporal Data. National ICT Australia Ltd, Australia.

Manfred J. van Bergen, et, al., 2000. Crater lakes of Java: Dieng, Kelud and Ijen. Bali: IAVCEI General Assembly.

Kompas.com/SABRINA ASRIL. khusus http://epaper.kompas.com . diakses tanggal 14-02-2014.

Purwanto dan Marhadi, SK, 2014. Integrasi Penginderaan Jauh Dan Sistem Informasi Geografi Untuk Analisis Dampak Spasial Erupsi Gunung Kelud Di Kabupaten Kedi- 
Purwanto, Marhadi Slamet K. Dinamika Spatio-Temporal Dampak Erupsi Gunung Kelud Di Kabupaten Kediri

ri, Blitar, Dan Malang. LP2M:

UM.

Rao, K.Venkateswara, et. all., 2011. An object-oriented modeling and implementation of spatio-temporal knowledge discovery system. International Journal of Computer Science \& Information Technology (IJCSIT), Vol 3, No 2, April 2011. Department of Computer Science and Engineering, CVR College of Engineering, RR District, Andhra Pradesh, India.

Santosa, S dan Atmawinata, S. 1992. Peta Geologi Lembar Kediri, Jawa. Bandung: Pusat Penelitian dan Pengembangan Geologi.

Sartohadi, Junun dan Pratiwi, elok surya. 2014. Bunga Rampai Penelitian Pengelolaan bencana Kegunungapian Kelud pada periode Krisis Erupsi 2014. Yogyakarta: Pustaka Pelajar.

www.Kompas.com diakses 14-02-2014

Yulianti, Mega Wirna, 2009. Penerapan Spatio Temporal Change Query pada Relational Database. IPB: Fakultas Ilmu Pengetahuan Alam.

Zaennudin, Akhmad.et all. 2013. Letusan Gunung Kelud pada $690 \pm 110$ tahun yang lalu merupakan letusan yang sangat dahsyat dan sangat berdampak pada Kerajaan Majapahit. Jurnal Lingkungan dan Bencana Geologi, Vol. 4 No. 2 Agustus 2013: 117 - 133 